\title{
Schools and Stimulus
}

Bill Dupor and M. Saif Mehkari

This article analyzes the impact of the education funding component of the American Recovery and Reinvestment Act of 2009 (Recovery Act) on public school districts. We use cross-sectional differences in district-level Recovery Act funding to investigate the program's impact on staffing, expenditures, and debt accumulation. To achieve identification, we use exogenous variation across districts in the allocations of Recovery Act funds for students with special needs. We estimate that $\$ 1$ million in grants to a district had the following average effects: Expenditures increased by $\$ 570,000$, employment changed little to none, and debt increased by $\$ 370,000$. Moreover, 70 percent of the increase in expenditures was in the form of capital outlays. Next, we build a dynamic, decision-theoretic model of a school district's budgeting problem, which we calibrate to district-level expenditures and staffing data. The model can qualitatively match the employment and capital expenditure responses from our regressions. We also use the model to conduct policy experiments. (JEL D21, D24, E52, E62)

Federal Reserve Bank of St. Louis Review, Second Quarter 2020, 102(2), pp. 145-71.

https://doi.org/10.20955/r.102.145-71

\section{INTRODUCTION}

The American Recovery and Reinvestment Act of 2009 (the Recovery Act) was signed into law with a primary goal of creating and saving millions of jobs during and following the 2007-09 recession. A large share of the appropriations from the act consisted of grants. Public school districts constituted one of the largest groups of these recipients, receiving \$64.7 billion in Department of Education Recovery Act funds. $\frac{1,2}{}$

The act's education component has been touted as one of the success stories by the law's supporters. Shortly after its passage, Vice President Joe Biden stated that funds from the act would "help to keep outstanding teachers in America's schools." Office of the President of the United States (2009, p. 4), "the rapid distribution of SFSF [State Fiscal Stabilization Funds] funding helped fill the gaps and avert layoffs of essential personnel

Bill Dupor is an assistant vice president and economist at the Federal Reserve Bank of St. Louis. M. Saif Mehkari is an associate professor of economics at the University of Richmond. The authors thank Peter McCrory for helpful research assistance.

(c) 2020, Federal Reserve Bank of St. Louis. The views expressed in this article are those of the author(s) and do not necessarily reflect the views of the Federal Reserve System, the Board of Governors, or the regional Federal Reserve Banks. Articles may be reprinted, reproduced, published, distributed, displayed, and transmitted in their entirety if copyright notice, author name(s), and full citation are included. Abstracts, synopses, and other derivative works may be made only with prior written permission of the Federal Reserve Bank of St. Louis. 


\section{Figure 1}

\section{Education and Noneducation Employment Growth in the United States, 1991-2016}

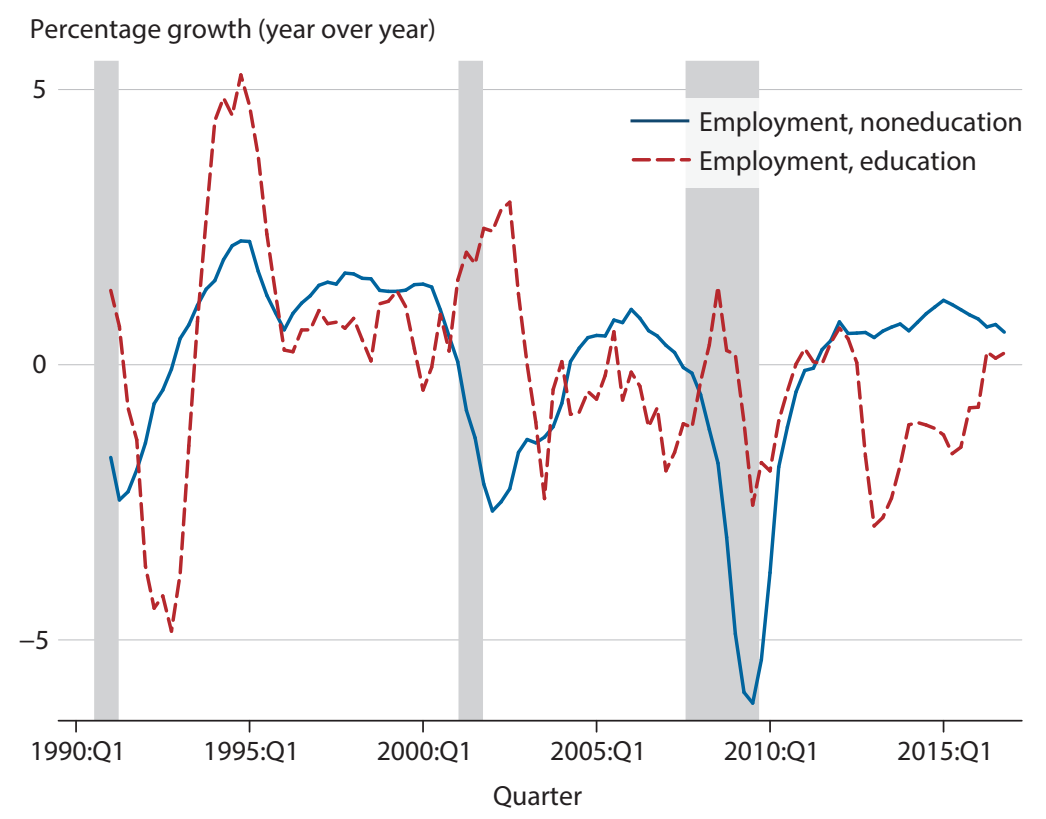

NOTE: Shaded bars indicate recessions as determined by the National Bureau of Economic Research. Growth rates are demeaned.

SOURCE: Bureau of Labor Statistics.

in school districts and universities across the nation." The act's official website, Recovery.gov, used surveys of recipient organizations to track the number of jobs payrolled by the act's funds. The Council of Economic Advisers (various quarterly reports) used the job-count data from these surveys as evidence of the act's success. $\stackrel{4}{ }$ According to these reports, Department of Education Recovery Act dollars alone directly created and saved over 750,000 jobs during the first two school years following the act's passage. 5 For context, Figure 1 plots the demeaned growth rates of education employment and noneducation, that is, total net of education employment between 1991 and 2016. Noneducation employment is the much more cyclical of the two.

This article analyzes the act's impact on schools, using cross-sectional differences in district-level Recovery Act grants and expenditures, staffing, and debt accumulation. We compare the behavior of districts receiving relatively little grant money with that of districts receiving generous grants. From this comparison, we infer what districts would have done without the grants.

To address the potential endogenity of spending, we employ two instruments. Our first instrument is the ratio of the number of special-needs students to the total number of students in each district. Our second instrument is the Recovery Act dollars received by a district through the act's Special Education Fund (SEF). The SEF was one category of the Recovery Act 
education component and constituted one-fifth of the education grants. Its allocation across districts was determined primarily by the requirement that districts finance their special-needs programs. Although each instrument is highly correlated with overall Recovery Act education spending, each is plausibly uncorrelated with the short-run business cycle and tax revenue situations faced by school districts.

We have four main findings. First, the grants had either no or only a small impact on education jobs. Each $\$ 1$ million of aid to a district resulted in roughly an average of 1.5 additional jobs within that district. The point estimate implies that, in the first two school years following its passage, the act increased education employment by 95,000 persons nationwide. Moreover, this estimate is not statistically different from zero.

We find no evidence that the grants increased the number of classroom teachers. Intuitively, district administrators may have shown a strong preference for maintaining teacher-to-student (teacher-student) ratios and, to a lesser extent, staff-to-student (staff-student) ratios. As such, school officials may have found margins other than firing or hiring with which to cover shortfalls or spend surpluses.

Second, each $\$ 1$ million of grants to a district increased its expenditures by $\$ 570,000$. Because districts already had substantial funds from local and state sources, the additional Recovery Act funds were effectively fungible. Thus, upon receipt of Recovery Act funds, state and local funding sources may have reduced their own contributions to district funding, thereby offsetting the act's grants.

Third, districts that received grants tended to accumulate more debt. Roughly 70 percent of the spending increases were capital expenditures, that is, spending on construction, land, or existing structures (CLS) and equipment. Why might districts have used these funds for capital improvement? Since this aid was temporary, school districts may have smoothed the benefits of the aid over time by making long-lived physical investments.

Fourth, we build and calibrate a model of dynamic decisionmaking by a forward-looking school district. We show that the small employment effect and relatively large investment effect fall out of a fully specified and realistic dynamic programming problem.

We also use our theoretical model as a laboratory to understand the effects of different types of policy. Our main finding is that forcing school districts to use all the stimulus money on labor has no additional effect on the employment outcome. School districts that are forced to use stimulus money only on employment reduce their labor spending from state and local funding sources and substitute this shortfall with stimulus money, leaving the net employment outcome unchanged. We show that an alternative policy requiring districts to spend most of their revenue (from both stimulus and state and local sources) has a more significant effect on employment.

With respect to existing work, there is little economic research on the act's education component. Two exceptions are Dinerstein et al. (2013), who study the impact of the act on universities, and Chakrabart and Setren (2011), who examine the impact of the recession and the early part of the Recovery Act on school districts in the state of New York. More generally, other studies using microeconomic evidence that study the overall impact of the Recovery Act have focused mainly on economy-wide labor market outcomes. These include Chodorow- 


\section{Dupor and Mehkari}

Reich et al. (2012); Conley and Dupor (2013); Dupor and McCrory (2018); Feyrer and Sacerdote (2012); and Wilson (2012).

Another line of research studies how federal grants to schools influence school spending. Gordon (2004) studies the impact of additional federal grants to school districts serving economically disadvantaged children through the No Child Left Behind Act of 2001. She finds that, although the additional federal grants initially caused a dollar-for-dollar increase in school spending, over time school districts offset those increases with reductions in their own contributions to education funding.

Lundqvist, Dahlberg, and Mork (2014) study the impact of intergovernmental grants to local governments in Sweden and find that the grants do not stimulate local public employment. Evans and Owens (2007) study the extent to which federal grants to fund new police hires increased the size of local police forces versus simply supplanting local funding. They found that for every four officers payrolled by a grant, in an accounting sense, a police force actually increased by only a little over two officers. $\underline{6}$

\section{EMPIRICAL ANALYSIS}

\subsection{The Data}

The Sample. Our unit of observation is a public school district. $\underline{7}$ During the 2010 school year (SY), there were 16,117 such districts in the United States. We restrict our attention to districts with more than 500 students during that year. We also exclude districts missing requisite data, which leaves 6,786 districts.

Outcome Variables ( $\Delta$ Job-Years, $\Delta$ Expenditures, and Debt accumulation). Our first outcome variable measures school district employment. It is the change in employment from a base of the 2007 SY over the first two school years in which the act was fully in effect: that is, the 2009 SY and the 2010 SY. 9 Employed persons include teachers, aides, guidance counselors, librarians, district administrators, and other support staff. The data are self-reported by school districts in the annual Common Core of Data Local Education Agency Universe Survey.

Let $Y_{j, k}$ denote employment by district $j$ during school year $k$. Then,

$$
\Delta \text { Job-years }_{j}=\frac{1}{\operatorname{Pop}_{j}} \sum_{k=2009}^{2010}\left(Y_{j, k}-Y_{j, 2007}\right),
$$

where Pop $_{j}$ is district- $j$ enrollment in the 2007 SY.

Our data on total expenditures $S_{j, t}$ and debt are from the annual Local Education Agency Finance Survey. From these variables, we calculate our next two outcome variables. We measure expenditures as the per student cumulative spending in the 2009 SY and 2010 SY relative to a pre-act baseline:

$$
\Delta \text { Expenditures }_{j}=\frac{1}{\operatorname{Pop}_{j}} \sum_{k=2009}^{2010}\left(S_{j, k}-S_{j, 2007}\right) \text {. }
$$


Debt accumulation is the change in the per student debt of a district over the two school years following the act's passage:

$$
\left.{\text { Debt } \operatorname{accum}_{j}=\frac{1}{\operatorname{Pop}_{j}}(\text { End of 2010SY Debt }}_{j}-\text { End of 2008SY Debt }{ }_{j}\right) .
$$

Treatment Variable ( $V)$. First, let $\tilde{V}_{j}$ be the Recovery Act dollars outlaid to school district $j$ from the time of enactment through 2011:Q2. .0 Outlaid dollars are defined as dollars paid by the federal government to a recipient organization. These amounts are constructed using quarterly reports filed by recipients on the website FederalReporting.gov. ${ }^{11}$ Finally, we scale by the district enrollment and report values in millions of dollars:

$$
V_{j}=\frac{\tilde{V}_{j}}{10^{6} \times \operatorname{Pop}_{j}} .
$$

Nearly all of the education dollars authorized by the act were outlaid by the end of 2011:Q2.

Instrument Variables ( $V^{S N}$ and $\left.V^{S E F}\right)$. Since the allocation of the act's school funding was perhaps in part endogenous, we use instrumental variables (IVs). We have two IVs. Our first IV is the ratio of the number of special-needs students within a district to the overall student enrollment in that district in 2007. 12 Denote this variable as $V_{j}^{S N}$. While the fraction of specialneeds students in a school district is likely to affect the Recovery Act funding that a district receives, it is plausibly uncorrelated with the business cycle conditions and tax revenue stress that the district faced.

Our second IV is the per student value of special-education funding outlaid as part of the Recovery Act, defined as $V_{j}^{\text {SEF }}$, through 2011:Q2.

The main channel through which the federal government supports special education is through the Individual's with Disabilities Act (IDEA). Most of the Recovery Act specialeducation money was tied to the IDEA program. While there are several subprograms within IDEA, the lion's share of funding comes through Part B of IDEA. The Recovery Act funding formula follows the IDEA Part B formula. $\underline{13}$

Recovery Act IDEA Part B grants were add-ons to regular annual IDEA Part B grants to states. The national federal fiscal year (FFY) 2009 regular grant amount was $\$ 11.5$ billion. The first $\$ 3.1$ billion (from both regular funding and the Recovery Act add-on) was divided among states so they were guaranteed to receive their FFY 1999 awards. Once this requirement was met, the remaining part of the national award was allocated among the states according to the following rule: " $85 \%$ are allocated to States on the basis of their relative populations of children aged 3 through 21 who are the same age as children with disabilities for whom the State ensures the availability of a free appropriate public education and $15 \%$ on the relative populations of children of those ages who are living in poverty." 14 The Recovery Act add-on totaled \$11.3 billion. Since, at the margin, the FFY 1999 requirements had already been met by the regular awards, every Recovery Act dollar was in effect assigned according to the 85/15 percent rule.

We now address how funds were assigned from state education agencies to local education agencies (LEAs). These initial allocations too were made at the federal level. Each LEA was 


\section{Dupor and Mehkari}

first allocated a minimum of its FFY 1999 award. $\frac{15}{}$ Beyond these minimums, which were already met by the regular annual award amounts, a slightly different $85 / 15$ rule was used. Within each state, 85 percent of the dollars were allocated according to the share of school-age children in the LEA and 15 percent were allocated according to the share of those children living in poverty. After meeting these stipulations, states were allowed to reallocate funds as explained below. Before we explain how reallocations worked, we ask whether the observed spending data at the within-state level are explained by the simple formulary rule.

Let $P_{j, s}$ and $\tilde{P}_{j, s}$ be the enrollment of students and students in poverty, respectively, in district $j$ and state $s$. Let $I D E A_{j, s}$ denote the total Recovery Act special-needs funding in district $j$ in state $s . \underline{16}$

Thus, within each state, the district-level per pupil IDEA amount would be perfectly predicted by the ratio of the enrollment of low-income students to the overall enrollment in the district if the simple formula were used. Next, we run state-level regressions to check this conjecture for the 46 states for which we have fully reported IDEA amounts. The $R^{2}$ values from these regressions are generally very low: 25 values are less than 0.01 . Only six of the $R^{2}$ values are greater than 0.1 and only one is greater than $0.3 . \underline{17}$ This tells us that factors other than the poverty rate in each district are influencing the allocation of IDEA funds.

This brings us to the rules for reallocation of dollars within states across LEAs, given by Code of Federal Regulation 300.707(c)(1). It states,

If an SEA [state education agency] determines that an LEA is adequately providing FAPE [free appropriate public education] to all children with disabilities residing in the area served by that agency with State and local funds, the SEA may reallocate any portion of the funds under this part...to other LEAs in the State that [are] not adequately providing special-education and related services to all children with disabilities residing in the area served by those LEAs.

Based on the legislation and given the low set of $R^{2}$ values above, we conclude that the primary reason that IDEA money was allocated differently from the formulary rule is that some states were able to meet their funding requirements for special-needs students in some districts without drawing on Recovery Act IDEA funds. These funds were then reallocated to districts with additional funding requirements for special-needs students. Differences in funding requirements across districts were likely due to factors such as the number of special-needs students, the types of disabilities and their associated costs, and the districts' own funding contributions for providing services to these special-needs students. Our exogeneity assumption is that this set of factors driving redistribution of IDEA funds is orthogonal to the error term in the second-stage equation.

Conditioning Variables $(X)$. We include the following conditioning variables, which we partition into three types:

- pre-recession education variables: the 2007 SY values of the teacher-student ratio, staffstudent ratio, and expenditures per pupil and the change in debt per pupil over the 2007 SY;

- nonfinancial variables: the ratio of African American plus Hispanic enrollment to total enrollment, the natural log of enrollment, seven regional dummy variables, and a constant; and 
Table 1

\section{Summary Statistics}

\begin{tabular}{|c|c|c|c|c|}
\hline Variable & Mean & SD & $\begin{array}{c}\text { 10th } \\
\text { Percentile }\end{array}$ & $\begin{array}{c}\text { 90th } \\
\text { Percentile }\end{array}$ \\
\hline Change in total revenue ( $\$ p p)$ & 838.85 & $3,186.31$ & $-1,778.23$ & $3,635.67$ \\
\hline Change in expenditures ( $\$ p p)$ & 689.81 & $5,140.74$ & $-3,492.91$ & $4,976.10$ \\
\hline Recovery Act education spending (\$pp) & $1,013.20$ & 766.98 & 446.04 & $1,569.25$ \\
\hline Recovery Act IDEA spending (\$pp) & 178.48 & 480.00 & 0.00 & 288.82 \\
\hline Change in the wage bill (\$pp) & 642.68 & $1,397.71$ & -926.05 & $2,256.92$ \\
\hline Change in the number of job-years ( $\$ p p)$ & 0.00 & 0.03 & -0.03 & 0.02 \\
\hline Debt accumulation (\$pp) & 59.69 & $7,443.66$ & $-2,381.30$ & $2,984.66$ \\
\hline Log of enrollment & 7.83 & 1.09 & 6.55 & 9.32 \\
\hline \multicolumn{5}{|l|}{2007 SY values of } \\
\hline Number of teachers (pp) & 0.06 & 0.01 & 0.05 & 0.08 \\
\hline Number of staff (pp) & 0.12 & 0.03 & 0.08 & 0.16 \\
\hline End of school year debt $(\$ p p)^{\dagger}$ & 10.88 & 2.99 & 8.23 & 14.40 \\
\hline One-year debt change (\$pp) & $3,653.55$ & $3,0046.28$ & $-3,000.00$ & $9,662.00$ \\
\hline Minority rate & 0.24 & 0.27 & 0.02 & 0.69 \\
\hline Poverty rate & 0.03 & 0.02 & 0.01 & 0.05 \\
\hline Self-sufficiency ratio & 0.41 & 0.20 & 0.19 & 0.71 \\
\hline
\end{tabular}

Total Recovery Act education spending $=\$ 36$ billion

Total Recovery Act IDEA spending $=\$ 7$ billion

Number of observations $=6,786$

NOTE: The unit of observation is a U.S. school district. The above sample excludes districts with enrollments less than 500 in the 2010 SY. ${ }^{+}$denotes a variable has been divided by 1,000 . SD, standard deviation; pp, per pupil.

- school district financials: the poverty rate, the fraction of revenue from local sources, and the cumulative change in revenue from nonfederal sources.

Details regarding a few of these variables are in order. The poverty rate is the number of young persons living in poverty relative to the total population of persons living within each school district's borders. The change in revenue from the nonfederal sources variable is given by

$$
\frac{1}{\operatorname{Pop}_{j}} \sum_{k=2008}^{2010}\left(R_{j, k}^{\text {non fed }}-R_{j, 2007}^{\text {non fed }}\right),
$$

where $R_{j, k}^{\text {non fed }}$ is the district- $j$ revenue from nonfederal sources in school year $k$. The primary nonfederal sources are from within the district and the state government.

Table 1 provides summary statistics for the variables in our analysis. 


\subsection{The Econometric Model}

We use two-stage least-squares regression for our estimations. The statistical model for the $\Delta$ Job-years equation is

$$
\begin{aligned}
V_{j} & =\theta_{1} V_{j}^{S E F}+\theta_{2} V_{j}^{S N}+\psi X_{j}+v_{j} \\
\Delta \text { Job-years }_{j} & =\beta_{J Y} \hat{V}_{j}+\gamma X_{j}+\varepsilon_{j},
\end{aligned}
$$

where $\hat{V}_{j}$ are the fitted values from the first-stage regression. The parameter of interest is $\beta_{J Y}$. The statistical model for the other two outcome variables simply replaces $\Delta$ Job-years $_{j}$ with $\Delta$ Expenditures $_{j}$ or Debt Accum $_{j}$. Our estimates are weighted by district enrollment, and we report robust standard errors (SEs).

\section{RESULTS}

\subsection{Benchmark Results}

The Employment Effect. Table 2 contains our benchmark estimates. Column (i) shows the job-years response to grants. The coefficient on education spending equals 1.47 ( $\mathrm{SE}=1.32$ ): Every $\$ 1$ million in grants increased district employment by 1.47 relative to a no-Recovery Act baseline. Note that our construction of the outcome variable is such that one job should be interpreted as lasting one year. This estimate is not statistically different from zero, but is estimated sufficiently precisely to conclude that the jobs effect was small at best. At the upper end of the 95 percent confidence interval, the employment effect was 4.05 jobs per \$1 million spent. We view this as quantitatively small, bearing in mind that the average education industry wage was roughly $\$ 50,000$ during this period. $\frac{18}{1}$ The estimates for other outcome variables (presented below), elucidate two reasons why there was a small effect, if any, on education jobs. First, a large portion of the grants did not translate into greater district-level expenditures. Second, district-level expenditures that did arise from the grants were used mainly for capital expenditures.

Next, using the job-years response estimate, we calculate the implied total number of education job-years resulting from the act's education component. Taken at the upper end of its 95 percent confidence interval, our estimate is 260,000 jobs. $\frac{19}{}$ As explained in the introduction, this is substantially lower than the corresponding number based on the payroll count data reported at Recovery.gov. $\underline{\underline{20}}$

The bottom rows of Table 2 report key statistics from the first-stage regressions. The firststage results indicate that we have two strong instruments. The partial $F$-statistic is 2,589.38, with a pointwise $t$-statistic of 11.72 for the special-education student-ratio instrument and 70.54 for the Special Education Funds instrument.

Our findings related to the jobs effect raise this question: Why were so few, if any, education jobs created as a result of the act? One possibility is that district administrators viewed their staff, particularly teachers, as so important to their mission that districts receiving relatively little aid found ways to close budget gaps without firing many staff. Also, districts that received relatively generous Recovery Act grants may have been less willing to hire new staff 


\section{Table 2}

\section{Estimates of the Impact on Staff Employment, Expenditures, and Debt Accumulation in \$1 Million of Recovery Act Education Grants, Benchmark Results}

\begin{tabular}{|c|c|c|c|}
\hline & $\begin{array}{l}\Delta \text { Staff jobs } \\
\text { (i) }\end{array}$ & $\begin{array}{c}\Delta \text { Total expenditures } \\
\text { (ii) }\end{array}$ & $\begin{array}{l}\text { Debt accumulation } \\
\text { (iii) }\end{array}$ \\
\hline Recovery Act education & $3.09 * * *(0.66)$ & $516.35^{* * *}(103.66)$ & $-254.38(162.75)$ \\
\hline $\operatorname{Ln}($ population) & $0.07(0.22)$ & $166.48^{* * *}(33.86)$ & $81.29(53.16)$ \\
\hline Minority ratio & $-0.02^{* * *}(0.00)$ & $1.54^{* * *}(0.21)$ & $-0.93^{* * *}(0.33)$ \\
\hline Poverty rate & $-0.02(0.02)$ & $-16.84^{* * *}(3.50)$ & $-1.31(5.49)$ \\
\hline Nonfederal spending change per pupil & $1.64^{* * *}(0.10)$ & $642.90^{* * *}(15.60)$ & $-114.60^{* * *}(24.49)$ \\
\hline Self-supporting school district & $-0.01(0.00)$ & $-1.65^{* * *}(0.28)$ & $1.01^{* *}(0.44)$ \\
\hline Teachers per pupil, lag & $-0.30 * * *(0.04)$ & $57.13^{* * *}(6.03)$ & $-30.30 * * *(9.46)$ \\
\hline Staff per pupil, lag & $-0.35^{* * *}(0.01)$ & $7.76^{* * *}(2.22)$ & $10.57^{* * *}(3.49)$ \\
\hline Total expenditures per pupil, lag & $0.00^{* * *}(0.00)$ & $0.00^{* *}(0.00)$ & $0.00(0.00)$ \\
\hline Debt change per pupil, lag & $0.00^{* * *}(0.00)$ & $0.00^{* *}(0.00)$ & $0.00^{* *}(0.00)$ \\
\hline Region dummies & Yes & Yes & Yes \\
\hline No. of observations & 7,519 & 7,519 & 0.03 \\
\hline$R^{2}$ & 0.30 & 0.37 & 0.69 \\
\hline \multicolumn{4}{|l|}{ First-stage results } \\
\hline Special ed. ratio (t-statistic) & 11.72 & 11.72 & 11.72 \\
\hline IDEA Recovery Act aid (t-statistic) & 70.54 & 70.54 & 70.54 \\
\hline Partial F-stat & $2,589.38$ & $2,589.38$ & $2,589.38$ \\
\hline
\end{tabular}

NOTE: Each estimation also includes additional conditioning variables described in the text. The regressions are enrollment weighted. SEs are in parentheses. ${ }^{* * *}$ denotes 1 percent and ${ }^{* *} 5$ percent statistical significance. The expenditure and debt accumulation variables are in units of thousands of dollars.

for risk that, once the short-lived grants were spent, the new staff would need to be laid off. Adjusting the capital outlays was an alternative way to spend grant dollars. We provide empirical evidence of and theoretical justification for a capital outlay response later in the article.

If neither districts receiving large grants nor those receiving small grants significantly adjusted their staff levels in response to the shock, then we should expect our IV estimates to reflect a small jobs effect. The absence of significant changes in staffing levels is consistent with narrative descriptions of districts' responses to the most recent recession. Cavanaugh (2011) explains that school officials initially responded to budget stress caused by the recession "at the periphery," for example, by cutting travel, delaying equipment upgrades, or scaling back extracurricular activities and art and music programs. Other evidence, based on surveys of school administrators, comes from the American Association of School Administrators (2012), which lists many ways that school administrators filled budget gaps during the period without firing employees. These include furloughing personnel, eliminating or delaying instructional improvement initiatives, deferring textbook purchases, and reducing high-cost course 


\section{Dupor and Mehkari}

offerings. While each of these strategies may have marginally reduced the quality of education services provided by the schools, the changes did not directly affect the total number of district employees.

Note that if jobs were created outside the district, perhaps because of a "Keynesian multiplier" effect, this is not reflected in our estimates, because we examine only school district employment.

The Expenditure Effect. Column (ii) of Table 2 reports estimates for the $\Delta$ Expenditure specification. The point estimate on Recovery Act education spending equals $\$ 516(\mathrm{SE}=\$ 103)$. This implies that $\$ 1$ million in education grants resulted in an increase in expenditures of approximately $\$ 516,000$ over the first two full school years following the act's passage. Thus, only about half of the aid to a district actually translated into more expenditures in that district. One explanation for this result may be that there was substantial "crowding out" of contributions by local and state governments to public education when school districts received Recovery Act dollars.

This finding relates to previous research on whether federal grants crowd out state and local spending. In a simple political economy model, Bradford and Oates (1971) show conditions under which crowding out occurs.

The Debt Accumulation Effect. Column (iii) of Table 2 presents the results with debt accumulation per pupil over the two years following the act's passage as the outcome variable. The point estimate on the Recovery Act spending variable is $-\$ 254$ ( $\mathrm{SE}=\$ 162)$. Based on the point estimate, districts that received relatively more aid tended to increase their debt positions.

\subsection{Additional Results}

Table 3 gives the responses of the outcome variables for several variations on the benchmark specification. Panels A and B provide the weighted and unweighted specifications, respectively. The first rows contain the benchmark estimates.

Column (i) of Table 3 presents the job-years estimates for all of the alternative specifications. The majority of estimates are close to the benchmarks. There are three things worth noting. First, not weighting by enrollment has very little effect on the estimate. Second, the "Ordinary least squares" (OLS) row is identical to the benchmark specification except we estimate via OLS rather than IVs. We expect that spending would have an expansionary effect on our outcome variables and money would be targeted toward more severely affected districts. Thus, the direction of endogeneity would suggest the OLS estimates are downwardly biased relative to our IV results. For job-years, the relative value of the point estimates are in the opposite direction; however, they are both quantitatively small and not statistically different from each other. Third, instrumenting with only the special-education ratio generates substantial increases in the jobs and expenditure effects relative to the benchmark specification. The job-years estimate increases to $8.04(\mathrm{SE}=7.36)$. Note that we are unable to reject a zero jobs effect for this specification. This specification results in the strongest jobs and expenditure effects of all of the alternative estimated models. Interestingly, the large jobs and expenditure effects are diminished substantially in the corresponding unweighted estimates (see Panel B). 


\section{Table 3}

Estimates of the Impact On Job-Years, Total Expenditures, and Debt Accumulation of \$1 Million in Recovery Act Education Funding, Alternative Specifications

\begin{tabular}{|c|c|c|c|c|}
\hline & $\begin{array}{c}\Delta \text { Job years } \\
\text { (i) }\end{array}$ & $\begin{array}{c}\Delta \text { Expenditures } \\
\text { (ii) }\end{array}$ & $\begin{array}{c}\text { Debt accumulation } \\
\text { (iii) }\end{array}$ & $\begin{array}{c}\text { First-stage partial } \\
\text { F-statistics } \\
\text { (iv) }\end{array}$ \\
\hline \multicolumn{5}{|c|}{ A: Weighted by enrollment } \\
\hline Benchmark & $1.47(1.32)$ & $570.10^{* * *}(196.60)$ & $340.63 *(185.12)$ & 79 \\
\hline Ordinary least squares & $2.11^{* *}(1.00)$ & $165.46(116.72)$ & $30.25(242.32)$ & N/A \\
\hline IDEA instrument only & $1.39(1.32)$ & $524.99 * * *(190.14)$ & $229.73(181.77)$ & 100 \\
\hline $\begin{array}{l}\text { Special-education ratio } \\
\text { instrument only }\end{array}$ & $8.04(7.36)$ & $2,339.31^{* * *}(815.61)$ & $3,977.68^{* * *}(1,352.86)$ & 30 \\
\hline Drop region dummies & $1.28(1.21)$ & $621.54^{* * *}(209.81)$ & $232.14(195.77)$ & 89 \\
\hline Drop all lagged variables & $0.97(1.07)$ & $216.97^{* *}(105.19)$ & $388.78^{* *}(186.16)$ & 78 \\
\hline \multicolumn{5}{|c|}{ B: Unweighted results } \\
\hline Benchmark & $0.12(0.63)$ & $346.08^{* * *}(125.01)$ & $461.15^{* * *}(164.84)$ & 540 \\
\hline Ordinary least squares & $-0.32(0.37)$ & $60.45(97.03)$ & $199.82(132.80)$ & N/A \\
\hline IDEA instrument only & $0.18(0.68)$ & $349.87^{* * *}(127.50)$ & 401.69 (159.89) & 1,027 \\
\hline $\begin{array}{l}\text { Special-education ratio } \\
\text { instrument only }\end{array}$ & $3.29(0.24)$ & $772.27(994.30)$ & $8,515.06^{* * *}(2,437.75)$ & 31 \\
\hline Drop region dummies & $0.09(0.53)$ & $323.39 * * *(125.15)$ & $588.84 * * *(195.27)$ & 572 \\
\hline Drop all lagged variables & $-0.19(0.24)$ & $145.13^{* *}(66.51)$ & $463.07^{* * *}(163.62)$ & 528 \\
\hline
\end{tabular}

Column (ii) of Table 3 presents the total expenditure estimates. (Recall that the coefficient is interpreted as the thousands of dollars by which expenditures increase for a $\$ 1$ million Recovery Act education grant to the district.) Thus, if the value is less than $\$ 1,000$, then there is some crowding out of grants because part of the aid is not passing through to expenditures. The majority of estimates are close to the benchmark estimate and exhibit substantial crowding out. Comparing the benchmark and OLS estimates, the direction of endogeneity bias is what one would expect.

Column (iii) of Table 3 presents the debt accumulation estimates. The benchmark estimate shows a statistically significant positive effect. All of the alternative specifications have a positive point estimate, with roughly one-half being statistically different from zero. The only outliers are the "Special-education ratio instrument only" cases, both weighted and unweighted. The point estimates for these specifications jump to about $\$ 4.0$ million and $\$ 8.5$ million, respectively. We view these values as implausibly large. For debt accumulation, the OLS estimate is lower than the IV estimate, which may be somewhat surprising.

Column (iv) of Table 3 contains the partial $F$-statistic for each specification. None of the values indicate a weak instrument problem, although the statistic is dramatically lower for the "Special-education ratio instrument only" specifications. 


\section{Table 4}

Estimates of the Impact of Staff Employment of \$1 Million Recovery Act Education Grants, By Job Type

\begin{tabular}{lcc} 
& $\begin{array}{c}\Delta \text { Teacher JY } \\
\text { (i) }\end{array}$ & $\begin{array}{c}\Delta \text { Nonteacher JY } \\
\text { (ii) }\end{array}$ \\
\hline Recovery Act education spending per pupil & $-0.03(0.51)$ & 1.50 (0.99) \\
\hline Full controls & Yes & Yes \\
\hline No. of observations & 6,786 & 6,786 \\
\hline Partial F-statistic & 78.93 & 78.93 \\
\hline $\begin{array}{l}\text { NOTE: Each estimation includes the conditioning variables described in the text. SEs are in parentheses. } \\
\text { JY, job-years. }\end{array}$ & \\
\hline
\end{tabular}

\section{Table 5}

Estimates of the Impact on Expenditures of \$1 Million of Recovery Act Education Funding, by Major Expenditure Categories

\begin{tabular}{|c|c|c|c|c|}
\hline & $\begin{array}{l}\Delta \text { Expenditures } \\
\text { (i) }\end{array}$ & $\begin{array}{l}\Delta \text { Capital } \\
\text { (ii) }\end{array}$ & $\begin{array}{l}\Delta \text { Salaries } \\
\text { (iii) }\end{array}$ & $\begin{array}{l}\Delta \text { Benefits } \\
\text { (iv) }\end{array}$ \\
\hline $\begin{array}{l}\text { Recovery Act education spending } \\
\text { per pupil (\$) }\end{array}$ & $570.10^{* * *}(196.60)$ & $390.82^{* * *}(149.34)$ & $8.92(41.23)$ & $79.38^{*}(48.00)$ \\
\hline Full controls & Yes & Yes & Yes & Yes \\
\hline No. of observations & 6,786 & 6,786 & 6,786 & 6,786 \\
\hline Partial F-statistic & 78.93 & 78.93 & 78.93 & 78.93 \\
\hline
\end{tabular}

Next, we consider the type of education jobs affected. Did the grants create and save teachers' jobs or those of other employees? Table 4 presents the estimates for the benchmark specification except we estimate the equation separately for the changes in the numbers of teaching and nonteaching employees.

Column (i) of Table 4 shows that there was no statistically significant effect on the number of teacher jobs created or saved. The point estimate equals -0.03 ( $\mathrm{SE}=0.51$ ). District administrators may have sought, as a top priority, to maintain class sizes at their pre-recession levels. This constancy may have been achieved by neither hiring nor firing teachers on net.

The employment effect came through nonteaching jobs. As seen in column (ii), each $\$ 1$ million resulted in $1.50(\mathrm{SE}=0.99)$ additional job-years of nonteaching employment, although this too is not statistically different from zero.

Next, Table 5 examines the categories of spending that account for most of the effect on total expenditures. In columns (ii) through (iv), we estimate the benchmark model except we 
in turn replace the change in total expenditures with the change in a component of total expenditures.

Column (ii) shows that Recovery Act aid had a substantial effect on capital outlays. Roughly 70 percent of all expenditures came in the form of capital outlays. .11 Why might districts have used so much of their grant money for investments? First, suppose a district seeks to keep its provision of education services as well as keep those provided services relatively smooth over time, in a manner similar to the permanent income model of consumption smoothing. Second, suppose education services are a function of labor (i.e., the number of staff) and capital. In this case, a district that receives a one-time grant may seek to spread the benefits of this grant over many periods by using part of the grant to increase its capital stock.

Likewise, a district that received a relatively small amount of aid may have found that the best way to close budget gaps was to temporarily cut back on capital investment rather than lay off staff. Because the capital stock depreciates slowly, a temporary interruption in investment would likely have only a small effect on the quality of education services that the school could provide.

Recall that earlier, we document that Recovery Act aid tended to increase debt accumulation. This effect may be related to the positive effect of aid on capital expenditures shown in Table 5. Suppose that, upon receipt of Recovery Act funds, a district decided to spend part of its funds on capital, such as construction. The district may have chosen to boost the dollars available for construction by leveraging up the grant aid by borrowing. Under this scenario, had the district attempted to finance the entire capital project only with debt, it may have been unable to secure the funds or get a reasonable financing rate. Thus, it is possible that grants may have led to borrowing rather than saving by some districts.

Note that the construction spending itself is likely to have a positive jobs effect because of building contractors the district might hire. These numbers are not reflected in our employment estimate, because we restrict attention to school district employees. $\underline{22}$

Column (iii) of Table 5 reports the impact of aid on salaries, which was small and not statistically different from zero. $\underline{\underline{23}}$ Since the employment effect was so small, it is not surprising that we do not recover a substantial wage effect. Column (iv) of Table 5 implies that $\$ 1$ million in aid increased benefits paid by the school district by about $\$ 79$ million.

\section{A MODEL OF SCHOOL DISTRICT HIRING AND CAPITAL DECISIONS}

In this section, we study the dynamic optimization problem of a school district facing stochastic revenue shocks.

In the previous section, we found that the ratio of stimulus spending for paying education workers relative to capital investment was 0.25 . This may be puzzling since, as we explain below, the long-run average of this ratio equals 8 . Second, there was a small effect on nonteacher staffing and no effect on the number of teachers employed. Our model simulations roughly match both of these findings.

Moreover, our model allows us to estimate the medium- and long-run effects of these grants and provides a laboratory to study the effects of alternative hypothetical stimulus programs aimed at schools. 


\section{Table 6}

Volatility of the Teacher-Student and Nonteacher-Student Ratios

\begin{tabular}{lcccc} 
& \multicolumn{3}{c}{$\begin{array}{c}\text { Time-series variance of log deviations from the } \\
\text { aggregate trend of the per student ratios }\end{array}$} \\
\cline { 2 - 5 } & $\begin{array}{c}\text { Teacher } \\
\text { (i) }\end{array}$ & $\begin{array}{c}\text { Nonteacher } \\
\text { (ii) }\end{array}$ & $\begin{array}{c}\text { Teacher } \\
\text { (iii) }\end{array}$ & $\begin{array}{c}\text { Nonteacher } \\
\text { (iv) }\end{array}$ \\
\hline 10th Percentile & 0.0012 & 0.0036 & 0.0004 & 0.0008 \\
\hline 25th Percentile & 0.0018 & 0.0062 & 0.0007 & 0.0017 \\
\hline Median & 0.0033 & 0.0122 & 0.0016 & 0.0038 \\
\hline 75th Percentile & 0.0062 & 0.0245 & 0.0039 & 0.0093 \\
\hline 90th Percentile & 0.0104 & 0.0555 & 0.0092 & 0.0232 \\
\hline Years & \multicolumn{3}{c}{$1994-2011$} & \\
\hline Number of districts & 1,901 & 4,291 & \\
\hline
\end{tabular}

\subsection{The Stylized Facts}

We begin by documenting two stylized facts about education spending by analyzing a 17 -year panel of district-level data ending with the 2011 SY. $\underline{24}$ The facts provide guidance for building and then calibrating our economic model.

Our panel covers a long time span, and some of our series contain time trends. As such, we detrend every variable $x_{t}$ by its aggregate (over districts) gross growth rate between period $t$ and $Q$, the final period in our sample. The cumulative growth rate is

$$
c g_{x, t}=\frac{\sum_{i \in I} x_{i, t}}{\sum_{i \in I} x_{i, Q}},
$$

where $I$ is the set of all districts. The detrended district-level variable is then $\tilde{x}_{t}$, thus

$$
\tilde{x}_{i, t}=\frac{x_{i, t}}{c g_{x, t}}
$$

Unless otherwise noted, each variable is scaled by its district enrollment.

Stylized Fact 1: The teacher-student ratio is less volatile than the nonteacher-student ratio.

For each district $i$, we compute the time-series variance of the log deviation of the employment levels of teachers, $T$, and nonteachers $\underline{25}, N$ :

$$
v_{x, i}=\text { variance across } t \text { of } \log \left[\frac{\tilde{x}_{i, t}}{\frac{1}{Q} \sum_{t} \tilde{x}_{i, t}}\right]
$$

for $x \in(T, N)$. 


\section{Table 7}

\section{Volatility of the Pay-to-Student and Capital-to-Student Ratios}

\begin{tabular}{lcc} 
& \multicolumn{1}{c}{$\begin{array}{c}\text { Time-series variance of log } \\
\text { deviations from the aggregate } \\
\text { trend of the per student ratio }\end{array}$} \\
\cline { 2 - 3 } & $\begin{array}{c}\text { Salary + benefits } \\
\text { (i) }\end{array}$ & $\begin{array}{c}\text { All capital outlays } \\
\text { (ii) }\end{array}$ \\
\hline 10th Percentile & 0.0013 & 0.3339 \\
\hline 25th Percentile & 0.0021 & 0.5860 \\
\hline Median & 0.0036 & 0.9580 \\
\hline 75th Percentile & 0.0064 & 1.4720 \\
\hline 90th Percentile & 0.0111 & 2.0509 \\
\hline Years & \multicolumn{3}{|}{$1994-2010$} \\
\hline Number of districts & 6,092 \\
\hline
\end{tabular}

Columns (i) and (ii) of Table 6 contain the across-district median values (along with the 10th, 25th, 75th, and 90th percentile values) of $v_{T, i}$ and $v_{N, i}$. Observe that the nonteacherstudent ratio is more variable than the teacher-student ratio. The difference in variability ranges from three times as high for the 10th percentile, four times as high for the median, and over five times as high for the 90th percentile.

As further robustness, columns (iii) and (iv) contain the statistics for a smaller subsample that includes data from the most recent six years. Whereas the shorter time horizon results in a reduced value of the magnitude of the variance, as in the full sample, in this subsample, the teacher-student ratio remains less variable than the nonteacher-student ratio.

Stylized Fact 2: Capital spending is more volatile than labor spending.

Next, we consider the behavior of two categories of spending: capital expenditures and labor expenditures. Capital expenditures are the sum of spending on CLS and equipment with an expected life of five or more years. Labor expenditures include salaries and benefits of district employees. $\frac{26}{}$ We convert each variable into real terms using the gross domestic product deflator with a base year of 2011 .

Table 7 reports the across-district median values (along with the 10th, 25th, 75th, and 90th percentile values) of the time-series volatility of expenditures on total real salary plus benefits and real capital outlays, where each volatility is calculated as the time-series variance of the $\log$ deviations of the variable from its aggregate trend using equation (4.1). Note that capital expenditures are significantly more variable than labor expenditures. At the median level of variability, capital expenditures are over 580 times more variable than labor expenditures.

We then divide the capital category into spending of two types: CLS and equipment. Table 8 reports the volatility of these variables. Even though the equipment component itself is volatile, most of the volatility in capital is driven by CLS. This fact, coupled with the facts 


\section{Table 8}

Volatility of the (Salary + Benefits)-to-Student and the Investment-to-
Student Ratios

\begin{tabular}{lccc} 
& \multicolumn{2}{c}{$\begin{array}{c}\text { Time-series variance of log deviations from the } \\
\text { aggregate trend of the per student ratio }\end{array}$} \\
\cline { 2 - 4 } & $\begin{array}{c}\text { CLS } \\
\text { (i) }\end{array}$ & $\begin{array}{c}\text { Equipment } \\
\text { (ii) }\end{array}$ & $\begin{array}{c}\text { All capital outlays } \\
\text { (iii) }\end{array}$ \\
\hline 10th Percentile & 0.5657 & 0.1141 & 0.3339 \\
\hline 25th Percentile & 1.0089 & 0.1861 & 0.5860 \\
\hline Median & 1.7008 & 0.3255 & 0.9580 \\
\hline 75th Percentile & 2.6626 & 0.5898 & 1.4720 \\
\hline 90th Percentile & 3.9451 & 1.1045 & 2.0509 \\
\hline Years & \multicolumn{4}{|}{6,092} \\
\hline Number of districts & & $1994-2010$ & \\
\hline
\end{tabular}

that CLS makes up roughly 80 percent of all capital investment and that labor expenditures are not highly volatile, pushes us toward a theory in which districts (i) tend to use large revenue gains and (ii) make up for revenue shortfalls largely by either investing in, or delaying expenditure on, long-lived capital goods.

\subsection{The Economic Model}

Consider a school district that uses an exogenous stream of revenue, $R$, to hire workers and buy capital to provide education services to its students. Its revenue process is given by the following $\mathrm{AR}(1)$ process:

$$
R^{\prime}=\rho R+(1-\rho) \bar{R}+\epsilon_{R} \text { with } \epsilon_{R} \sim \mathcal{N}\left(0, \sigma_{R}\right)
$$

where $\rho \in(0,1)$ and $\bar{R}$ is fixed. Revenue, as well as other variables in the model, are per pupil.

A district's one-period welfare function is

$$
W(T, N, K)=\alpha U\left(T ; \xi_{T}\right)+\gamma U\left(N ; \xi_{N}\right)+\eta U\left(K ; \xi_{K}\right),
$$

where $T, N$, and $K$ are the number of teachers, number of nonteachers, and quantity of capital, respectively. Moreover, let $U(X ; \xi)=X^{1-\xi} /(1-\xi)$. The function $W$ depends on inputs that improve "student outcomes," broadly defined.

The district's dynamic optimization problem is given by the following recursive functional equation:

$$
V(K ; R)=\max _{T, N, I}\left\{W(T, N, K)+\beta E\left[V\left(K^{\prime} ; R^{\prime}\right) \mid R\right]\right\}
$$

subject to 


$$
\begin{gathered}
R=w_{T} T+w_{N} N+I \\
K^{\prime}=(1-\delta) K+I
\end{gathered}
$$

and nonnegativity constraints on $T, N$, and $K$. Also, I represents investment in the capital good, and values with a superscript prime give the next-period realization of that variable. For example, $K^{\prime}$ gives the next-period realization of capital, $K$.

Next, equation (4.3) is the district budget constraint, with $w_{T}$ and $w_{N}$ representing the teacher wage and nonteacher wage, respectively. Also, equation (4.4) is the capital law of motion and $\delta$ is the capital depreciation rate.

Every period the school district receives revenue that it optimally allocates to (i) the hiring of teachers and nonteachers and (ii) capital acquisition. Whereas the number of teachers and nonteachers hired affects only the current period's welfare, the durable nature of capital results in a multiperiod effect. As we discuss in the next section, the dynamics that result from allowing the district to choose a durable input are important for understanding why the 2009 Recovery Act had a small effect on hiring but a large effect on capital outlays.

\subsection{Calibration and Simulations}

Table 9 provides the parameter values for the model. The model period is one year. We begin our calibration by setting the discount factor $\beta=0.96$ to match a 4 percent annual real interest rate.

Next, in the data, the capital stock is composed of two different basic types: equipment with more than a five-year lifespan and CLS. CLS account for roughly 75 percent of the capital outlays and depreciate at a 1.88 percent annual rate, while equipment accounts for roughly 25 percent of capital outlays and depreciates at a 15 percent annual rate. $\frac{27}{}$ As such, we set $\delta=0.0516(=0.75 \times 0.0133+0.25 \times 0.16)$.

Across districts, the median wage bill per student is $\$ 8,128$, for which 48 percent goes toward teacher pay and 52 percent goes toward nonteaching staff pay. Thus, teacher compensation is $\$ 3,901$ and nonteacher compensation is $\$ 4,227$ per pupil. The median teacher-student ratio is $1: 15.5$, and the median nonteacher-student ratio is $1: 16$. As a result, teacher and nonteacher wages are set at $w_{T}=\$ 60,472(=15.5 \times \$ 3,901)$ and $w_{N}=\$ 67,625(=16 \times \$ 4,227)$, respectively.

The persistence of the $\mathrm{AR}(1)$ revenue process is directly estimated from the data. The median autocorrelation of expenditures is 0.47 . The average revenue is set at $\bar{R}=\$ 8,128+\$ 988$ $=\$ 9,116$.

Six parameters remain: The welfare elasticities, $\xi_{T}, \xi_{N}$, and $\xi_{K}$; the relative shares of teachers, $\alpha$, and nonteachers, $\gamma$; and the standard deviation of the revenue process, $\sigma_{R}$.

First, we set $\xi_{K}=1.0$ and then jointly calibrate the remaining five parameters to match the following five targets: The average teacher-student ratio is ; the average nonteacher-student ratio is 0.062 ; the nonteacher-student ratio is four times as volatile as the teacher-student ratio; the average salary volatility is 0.0036 ; and the average investment volatility is 0.95 . 


\section{Dupor and Mehkari}

\section{Table 9}

\section{Parameter Values}

\begin{tabular}{|c|c|c|c|}
\hline Parameter & Value & Description & Explanation \\
\hline$\beta$ & 0.96 & Discount factor & Standard value for annual discount factor \\
\hline$* \delta$ & 0.0516 & Depreciation rate & $\begin{array}{l}\text { Calculated using the BEA data on the depreciation of buildings } \\
\text { and equipment }\end{array}$ \\
\hline$w_{T}$ & $\$ 60,472$ & Wage rate for teachers & Set equal to avg. teacher wage in the data \\
\hline$w_{N}$ & $\$ 67,625$ & Wage rate for nonteachers & Set equal to avg. non-teacher wage in the data \\
\hline $\bar{R}$ & $\$ 9,116$ & Average revenue per pupil & Sum of average revenue on labor + capital \\
\hline${ }^{*} \rho$ & 0.47 & Persistence of revenue process & $\begin{array}{l}\text { Set equal to the autocorrelation of district-level expenditures in } \\
\text { the data }\end{array}$ \\
\hline$\xi_{K}$ & 1.0 & Welfare elasticity of capital & Normalized to 1 \\
\hline$\xi_{T}$ & 1.52 & Welfare elasticity of teachers & \multirow{5}{*}{$\begin{array}{l}\text { Jointly calibrated to match (i) avg. teacher-student ratio }=0.064 \text {, } \\
\text { (ii) avg. nonteacher-student ratio }=0.062 \text {, (iii) teacher-student } \\
\text { ratio } 4 \text { x more volatile than nonteacher-student ratio, (iv) volatility } \\
\text { of total salary }=0.0036 \text {, and ( } v \text { ) avg. volatility of investment }=0.95\end{array}$} \\
\hline$\xi_{N}$ & 0.76 & Welfare elasticity of nonteachers & \\
\hline$a$ & 0.086 & Welfare share for teachers & \\
\hline$\gamma$ & 0.751 & Welfare share for nonteachers & \\
\hline$\sigma_{R}$ & 1,150 & SD of shock to revenue & \\
\hline
\end{tabular}

NOTE: SD, standard deviation; BEA, Bureau of Economic Analysis; avg., average.

\subsection{The Effect of a Recovery Act-Sized Shock}

To simulate the effects of the Recovery Act, we alter equation (4.3) to

$$
R+A=w_{T} T+w_{N} N+I
$$

where $A$ denotes the net magnitude of the Recovery Act shock to revenue after accounting for any loss in revenue at the district level. From our benchmark regression analysis (see Table 2), we estimate the size of this shock to be $\$ 570$ per student. As a result, we set $A=\$ 570$ in the period of the shock and $A=\$ 0$ otherwise. For a transparent comparison with our regression results, all results below are for a $\$ 1$ million shock. In the data, the gross magnitude of the Recovery Act shock before accounting for any loss in revenue at the district level was approximately $\$ 1,000$ per student. As a result, to find the $\$ 1$ million response, we multiply the per student values by 1,000 .

Figure 2 plots the effect of the spending shock. The left panels show the per period impulse responses, and the right panels show the cumulative responses. As seen in the figure, over the first two years, the additional revenue creates 1.4 nonteaching staff jobs and 0.7 teaching jobs and increases investment by $\$ 435,000$ for each $\$ 1$ million spent. Note that other than the size of the shock, the model was calibrated independently of the regression results. Consequently, the consistency between our regression results and the dynamic model provides further evidence for a small effect of the Recovery Act on employment. 


\section{Figure 2}

\section{Impulse Responses to a Recovery Act-Sized Shock}

\section{A. Investment}

Investment/Student

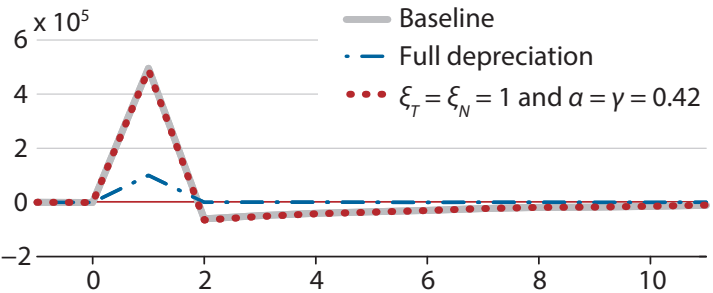

C. Teachers

Teachers/Student

3

2

$1-i$ i

$0 \ldots \ldots \ldots \ldots \ldots \ldots \ldots \ldots \ldots \ldots \ldots \ldots \ldots \ldots \ldots \ldots \ldots$

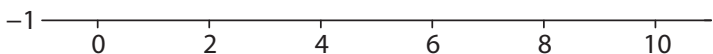

E. Nonteaching staff

Nonteachers/Student

6

4

$2+i$

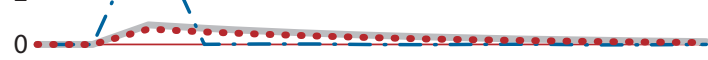

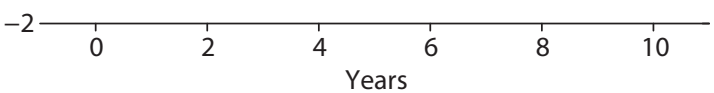

\section{B. Investment: cumulative effect}

Investment/Student

$6 \times 10^{5}$

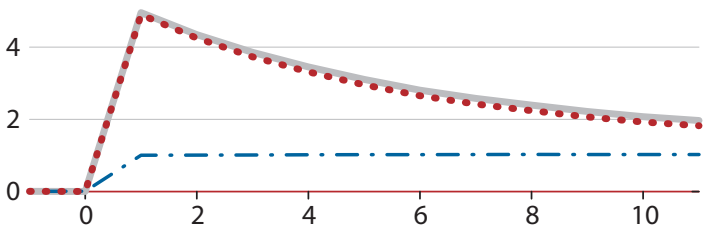

D. Teachers: cumulative effect

Teachers/Student

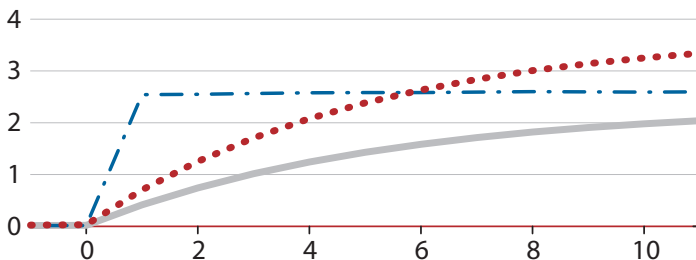

F. Nonteaching staff: cumulative effect

Nonteachers/Student

6

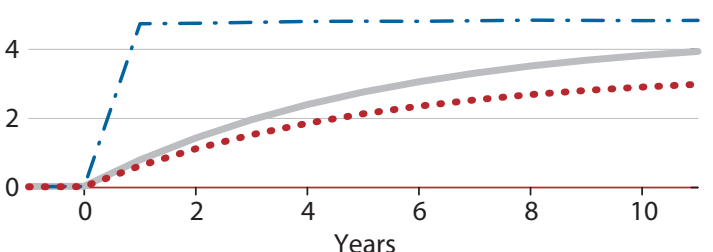

The large effect on investment is driven by a motive to smooth the value of education inputs over time. For the purpose of intuition, suppose a school district had two mutually exclusive uses of new funds: (i) increasing the number of staff for one year or (ii) engaging in additional investment for one year. The latter option leads to more capital in both the short and the intermediate runs, which increases education services. Also, since the capital is now higher, the district can cut back marginally on investment in periods after the shock and use the funds saved to increase its staffing levels. The latter option leads to an increased and smoother path of inputs over time-as well as higher welfare.

To illustrate this effect, Figure 2 graphs the responses of the district in a calibration where $\delta=1.0$; that is, capital depreciates fully after one period. As the figure shows, once the district loses access to interperiod savings, the employment effect increases. 


\section{Dupor and Mehkari}

Note that our environment does not permit the district to smooth the benefit of the revenue shock over time using savings or a similar means to deficit reduction. If we were to extend the model to permit these options, districts would use these financial instruments as well as capital accumulation in an optimal policy. Note, however, that our regression results instead find that deficits increased upon receipt of Recovery Act grants. As explained earlier, the increased deficits may be a result of districts pairing new capital spending with increased leverage through higher debt levels.

Next, one of our stylized facts was that the volatility of the number of teachers is significantly lower than that of nonteachers. We conjecture that this occurs because there may be little flexibility in hiring or laying off teachers. Consider a school that teaches five subjectsmath, English, Spanish, social studies, and science - to 80 students and currently hires one teacher for each subject. This school may be unable to lay off a teacher because doing so would lead to one fewer subject being taught. If the school wanted to add one teacher, the additional teacher could not teach a bit of all five subjects. Thus, the marginal benefit of hiring, say, one extra math teacher, is very low. On the other hand, hiring nonteaching staff across the district likely would not face classroom indivisibilty constraints. The relatively low volatility of teacher employment can be achieved in the model with a high value of $\xi_{T}$ relative to $\xi_{N}$. Thus, $\xi_{T}>\xi_{N}$ proxies for relatively low flexibility in changing the teaching-staff level. Figure 2 plots impulse responses if $\xi_{T}=\xi_{N} \cdot \underline{28}$ When the elasticities for teachers and nonteachers are identical, the response between them is more closely aligned.

Our model also permits us to estimate the shock's long-run effects. As discussed earlier, the initial effect of the shock is driven largely by an education-services-smoothing motive that results in accumulating capital initially. This, in turn, frees up future resources for hiring teachers and nonteachers. As shown in Figure 2, the cumulative 10-year effect is approximately two teachers and four nonteachers per $\$ 1$ million spent. Note that these effects are larger than the two-year effect. The long-run effect still dwarfs the Council of Economic Adviser's estimate that over 750,000 education jobs were created or saved by the act. At 2.25 jobs per $\$ 1$ million in two years and six jobs per $\$ 1$ million in 10 years, the $\$ 64.7$ billion spent by the Department of Education creates 146,000 jobs in the first two years and 388,000 jobs in the first 10 years following the act's passage.

Policy Analysis. Our model provides a laboratory to study the effects of alternative ways to implement a stimulus program. First, a simple—and it turns out simplistic-policy would require all districts to use stimulus money only on employment; that is,

$$
A \leq w_{T} T+w_{N} N
$$

Figure 3 plots the response to this policy. The policy has no effect relative to the "no constraint" case presented above. This is because a district's existing revenue and the stimulus money are fungible. In response to a stimulus shock, a district can cut back on using its existing revenue to pay labor and instead use the stimulus money to hire workers. The district would meet the requirement of using stimulus money to hire workers and maintain the no-constraint outcome. 


\section{Figure 3}

\section{Impulse Responses to a Recovery Act-Sized Shock: All Funding Used on Labor}

\section{A. Investment}

Investment/Student

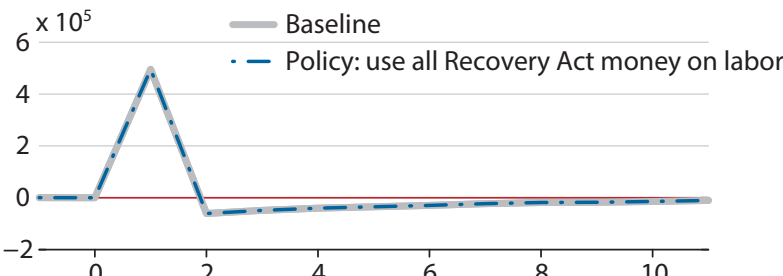

C. Teachers

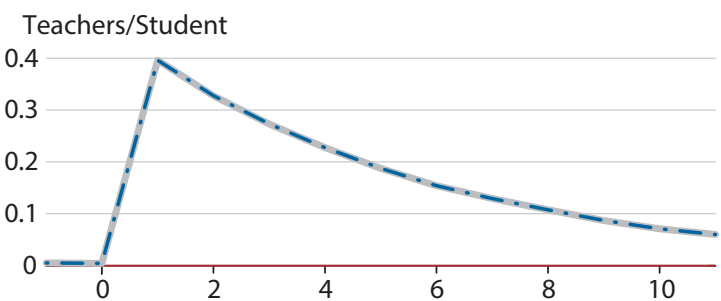

E. Nonteaching staff

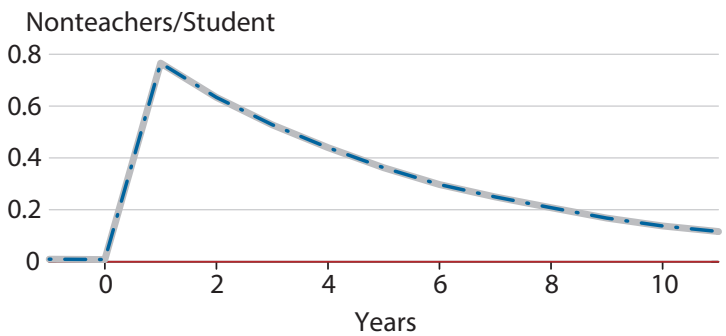

B. Investment: cumulative effect

Investment/Student

$6 \times 10^{5}$

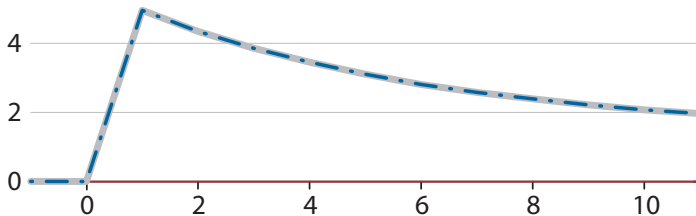

D. Teachers: cumulative effect

Teachers/Student

3

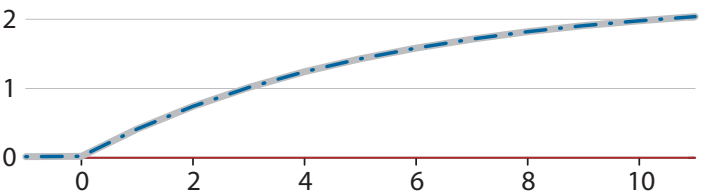

F. Nonteaching staff: cumulative effect

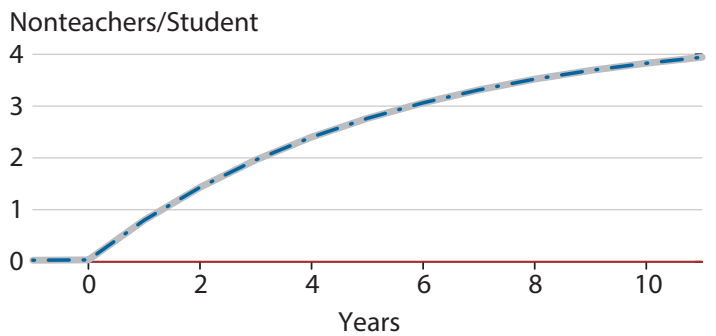

Consider an alternative policy where, instead, the federal government requires that in the period of the shock at least a fraction $\phi$ of all revenue must be used to pay workers:

$$
\phi(R+A) \leq w_{T} T+w_{N} N .
$$

We simulate the model under this policy, setting $\phi=0.875$, which we find achieves the maximum employment effect (while keeping investment constant). Figure 4 gives the results of this exercise: There is a significantly larger response, with nine new jobs (three teaching plus six nonteaching) in the year of the shock.

Our model also allows us to consider much richer policy alternatives where the percentage of revenue depends on the amount of revenue and capital at the district level. In Figure 5, we first calculate the pre-stimulus response of the district and then require the district to use all 


\section{Dupor and Mehkari}

\section{Figure 4}

\section{Impulse Responses to a Recovery Act-Sized Shock: Part of Funding Used on Labor}

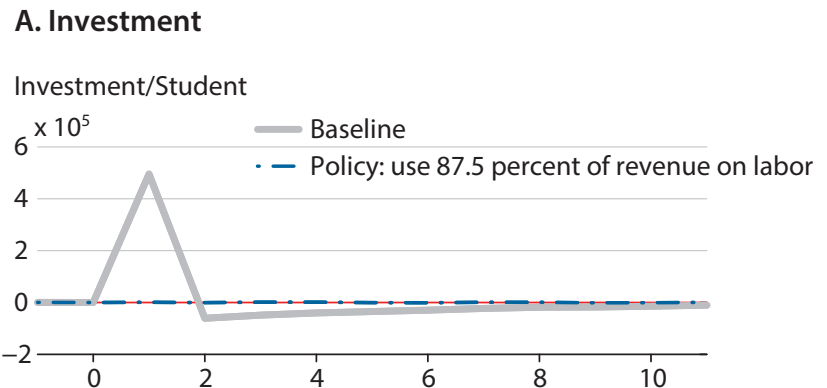

\section{B. Investment: cumulative effect}

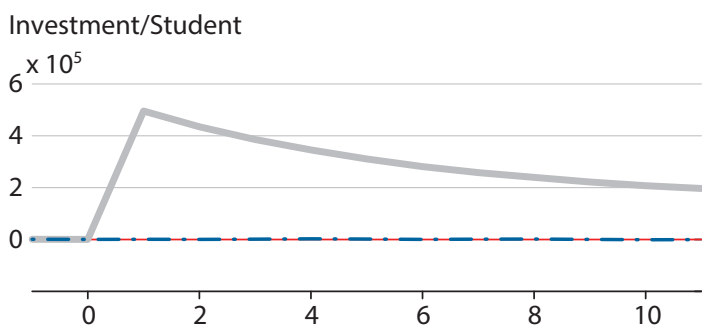

\section{Teachers}

D. Teachers: cumulative effect

Teachers/Student

3

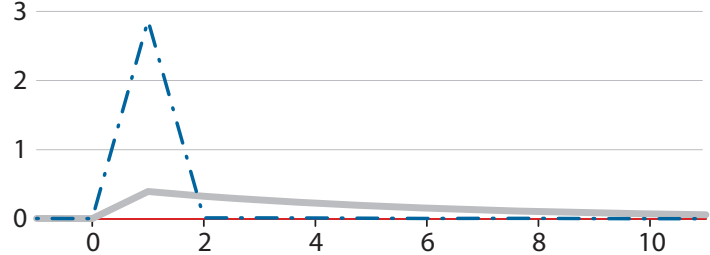

\section{E. Nonteaching staff}

Nonteachers/Student

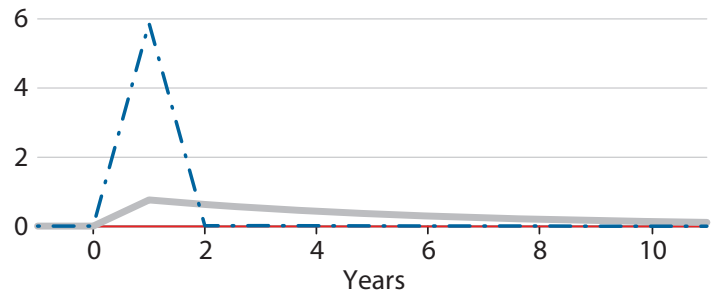

Teachers/Student

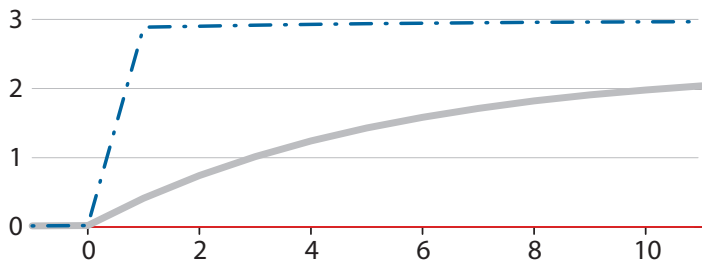

F. Nonteaching staff: cumulative effect

Nonteachers/Student

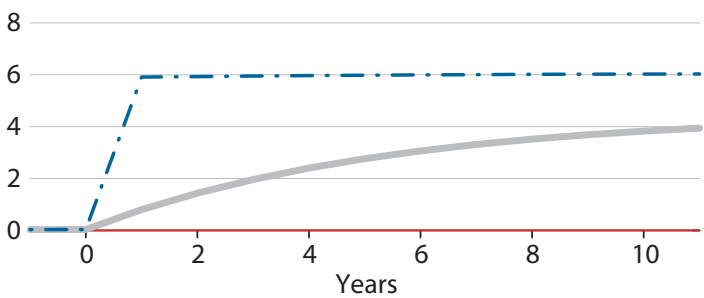

its stimulus revenue plus all revenue it would have used toward hiring labor had it not received the stimulus revenue. The figure then plots what percentage of the total post-stimulus revenue this amount would have been.

As Figure 5 shows, optimal policy is for the government to impose that a larger percentage of revenue be used on labor in districts with lower revenues and high levels of capital. Districts with lower levels of revenue in particular would be motivated to use the additional stimulus revenue received from the government on capital. 


\section{Figure 5}

\section{Optimal Policy: Heterogeneous Policy Analysis to Generate Maximum Employment Effects}

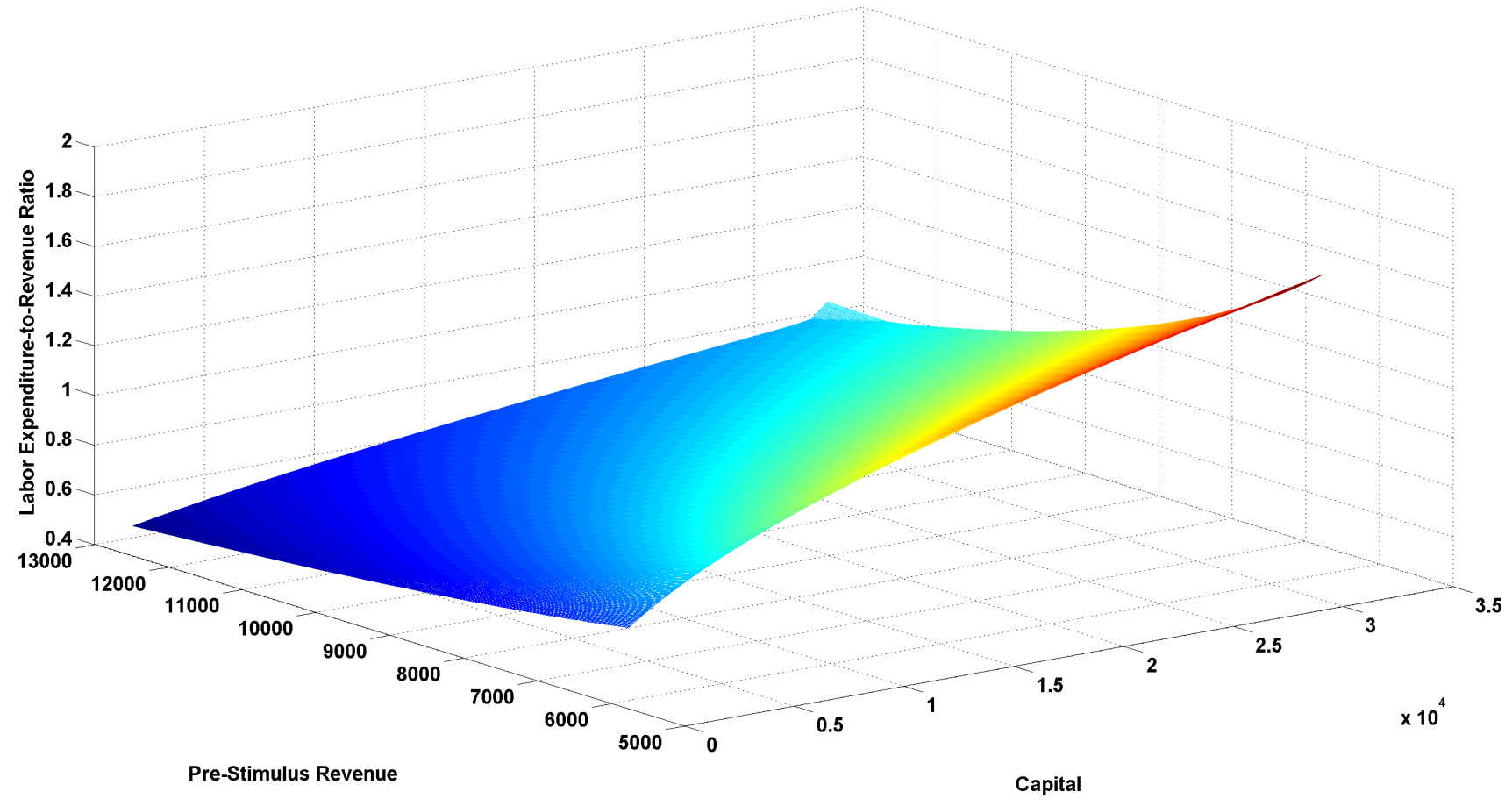

\section{CONCLUSION}

This article explores the impact of countercyclical government spending on the education sector. Empirically, we find that the Recovery Act's education component had a small effect on nonteacher staff levels, no effect on teacher staff levels, and a substantially less than onefor-one response of district-level expenditures. To the extent that government grants increased district expenditures, the increases largely took the form of capital outlays. The grants also stimulated district debt accumulation.

These findings should not be entirely surprising given the decentralized nature of the act's implementation plan. The allocation process was multitiered, with local and state governments allowed latitude as to how Recovery Act dollars were spent. First, state governments maintained substantial control over how they spent their own revenue. This created an environment where stimulus dollars might be used to replace state contributions. $\underline{29}$

After passing through the state level, the Recovery Act dollars were spent by individual districts largely at their own discretion. Given that the stimulus dollars were temporary, districts had an incentive to smooth out the spike in additional education services that they could provide by investing in equipment and structures. This objective is one potential explanation for the small employment effect estimated in this article. 


\section{APPENDIX}

\section{Table A.1}

\section{Number of Jobs Directly Created and Saved Through \\ Grants, Contracts, and Loans Administered by the \\ U.S. Department Of Education, First Two School Years Following Enactment of the Recovery Act}

\begin{tabular}{lc} 
Quarter & Education jobs \\
\hline 2009:Q3 & $397,982.43$ \\
\hline 2009:Q4 & $423,616.33$ \\
\hline $2010: Q 1$ & $470,197.34$ \\
\hline $2010: Q 2$ & $454,281.08$ \\
\hline $2010: Q 3$ & $344,308.14$ \\
\hline $2010: Q 4$ & $309,187.21$ \\
\hline 2011:Q1 & $319,494.26$ \\
\hline 2011:Q2 & $307,901.15$ \\
\hline Total (annualized) & $756,741.99$ \\
\hline NOTE: Jobs are measured units of full-time equivalents. \\
\hline SOURCE: Recovery.gov.
\end{tabular}

\section{NOTES}

1 This includes the Office of Special Education and Rehabilitative Services Special Education Fund (SEF) (\$12.2 billion) and the following Office of Elementary and Secondary Education programs: Education Stabilization funds (\$42.0 billion), Compensatory Education for the Disadvantaged ( $\$ 12.4$ billion) and the School Improvement Program (\$0.7 billion).

$\underline{2}$ The federal government's objectives for each of the programs were explicit and usually involved, in part, an attempt to stimulate economic activity. For example, recipients were advised that "Among other things, the Education Stabilization funds may be used for activities such as: paying the salaries of administrators, teachers, and support staff; purchasing textbooks, computers, and other equipment," according to U.S. Department of Education (2009a) implementation guidance.

3 See Biden (2011).

4 See also Congressional Budget Office (various quarterly reports).

$\underline{5}$ See Table A.1 in the appendix for a quarterly breakdown of the payroll count data extracted from Recovery.gov. Here, a job is measured as lasting one year and as a "full-time equivalent" of one respective position.

6 See also Knight (2002) for another example of crowding out of federal grants on state government spending.

$\underline{7}$ Our usage of the term "school district" is synonymous with the term "local education agency" (LEA) used in the education policy area. In the education policy jargon, our sample is made up of school districts and a small number of regional educational service agencies.

8 For example, we were forced to exclude data from all districts in lowa, Montana, New Hampshire, Pennsylvania, and Vermont because the Recovery Act spending information was reported in a manner that did not allow us to match the Recovery Act grants to school district spending and employment variables. We also excluded Hawaii because the entire state is a single school district. 
9 We exclude the 2008 SY because it includes only a few months during which the Recovery Act was in effect.

10 We use outlays through 2011:Q2 because this aligns our Recovery Act data sample with the end of the 2010 school year.

11 After processing and data verification by the Recovery Accountability and Transparency Board, these data were posted on the website Recovery.gov. A user's guide for these data is contained in Recovery Accountability and Transparency Board (2009).

12 These data are also from the Common Core of Data Universe Survey. As the data documentation explains, specialneeds students are defined as "all students having a written Individualized Education Program (IEP) under the Individuals with Disabilities Act (IDEA), Part B." The IDEA is a comprehensive statute originally passed in 1990 to ensure all students with disabilities are entitled to a free appropriate public education.

13 See U.S. Department of Education (2009b) and New America Foundation (2014).

14 See Enclosure B of U.S. Department of Education (2009b), which contains a description of the allocation of Recovery Act funds across states.

15 Federal code also describes how minimum awards are determined for LEAs created after 1999.

16 Based on the above formula, the distribution of Recovery Act IDEA funds would be

$$
I D E A_{j, s}=\left(0.85 \times \frac{P_{j, s}}{\sum_{i=1}^{N_{s}} P_{i, s}}+0.15 \times \frac{\tilde{P}_{j, s}}{\sum_{i=1}^{N_{s}} \tilde{P}_{i, s}}\right) I D E A_{s} .
$$

Letting $P_{s}$ and $\tilde{P}_{s}$ denote the sum within state of the two district-level enrollment variables, we can rewrite the above equation as

$$
\frac{I D E A_{j, s}}{P_{j, s}}=\left[0.85 \times \frac{1}{P_{s}}+0.15 \times \frac{1}{\tilde{P}_{s}}\left(\frac{\tilde{P}_{j, s}}{P_{j, s}}\right)\right] I D E A_{s} .
$$

17 As an additional measure, we include the poverty rate as an additional control in our estimation.

18 The mean annual wage for U.S. workers in the "Education, Training and Library" occupation was \$49,530 in 2009.

19 We calculate this number by multiplying the 95 percent upper bound of the job-years coefficient confidence interval by the cumulative total Recovery Act education spending through the $2010 \mathrm{SY}$. This calculation assumes that the treatment effect is the same for districts within our sample as for those excluded from the sample.

20 See Table A.1 in the appendix for a tabulation of the Council of Economic Advisers payroll count data.

$\underline{21}$ Capital outlays include spending on CLS and equipment.

$\underline{22}$ Dupor and McCrory (2018) conduct a cross-regional analysis of the act in a broader context than only education. That paper examines employment from all sectors and the act's entire spending component, in contrast to that solely from education. They find a larger jobs effect than that estimated in the current article.

$\underline{23}$ The salary and benefits variables are constructed in the equivalent manner as the variable for total expenditures was constructed.

24 We use the merged Universe and Finance surveys of the Common Core School District dataset. The 1994 SY is the first year for which the entire dataset is available. As in the article's previous section, we drop districts that report fewer than 500 students.

$\underline{25}$ Nonteaching staff includes instructional aides, guidance counselors, library/media staff, administrative support staff, and so on.

26 We exclude services and nondurable goods expenditures in our descriptions here. In regression results not provided in the article (but available on request), we establish that there was a negligible effect of grants on these types of spending. We also exclude debt service payments, payments to other districts, and expenditures on nonelementary/secondary programs because they make up only 10 percent of the average district's spending and are outside of our model.

27 See "BEA Depreciation Estimates" at https://apps.bea.gov/iTable/index FA.cfm. 


\section{Dupor and Mehkari}

$\underline{28}$ The values of $\alpha$ and $\gamma$ are jointly determined with $\xi_{T}$ and $\xi_{N}$.

$\underline{29}$ As Inman (2010, Abstract) writes, "States are important 'agents' for federal macro-policy, but agents with their own needs and objectives."

\section{REFERENCES}

American Association of School Administrators. "Weathering the Storm: How the Economic Recession Continues to Impact School Districts." March 2012;

https://www.aasa.org/uploadedFiles/Policy and Advocacy/files/Weathering the Storm Mar_2012 FINAL.pdf.

Biden, J. “Roadmap to Recovery." 2011; http://www.whitehouse.gov.

Bradford, D. and Oates, W. "The Analysis of Revenue Sharing in a New Approach to Collective Fiscal Decisions." Quarterly Journal of Economics, 1971, 85, pp. 416-39; https://doi.org/10.2307/1885931.

Cavanaugh, S. "Education Regroups in Recession's Aftermath." Education Week, 2011, 30, p. 6.

Chakrabarti, R. and Setren, E. "The Impact of the Great Recession on School District Finances: Evidence from New York." Staff Report 534, Federal Reserve Bank of New York, 2011; https://doi.org/10.2139/ssrn.1979694.

Chodorow-Reich, G.; Feiveson, L.; Liscow, Z. and Woolston, W. “Does State Fiscal Relief During Recessions Increase Employment? Evidence from the American Recovery and Reinvestment Act." American Economic Journal: Economic Policy, 2012, 4, pp. 118-45; https://doi.org/10.1257/pol.4.3.118.

Congressional Budget Office. "Estimated Impact of the American Recovery and Reinvestment Act on Employment and Economic Output." Various quarterly reports; http://www.cbo.gov/sites/default/files/05-25-arra_0.pdf. (Note that each report has a different URL. The URL to one of the reports is provided.)

Conley, T. and Dupor, B. "The American Recovery and Reinvestment Act: Solely a Government Jobs Program?" Journal of Monetary Economics, 2013, 60, pp. 535-49; https://doi.org/10.1016/j.jmoneco.2013.04.011.

Council of Economic Advisers. "The Economic Impact of the American Recovery and Reinvestment Act of 2009." Various quarterly reports; http://www.whitehouse.gov/sites/default/files/cea 8th arra report final draft.pdf (Note that each report has a different URL. The URL to one of the reports is provided ).

Dinerstein, M.; Hoxby, C.; Meyer, J. and Villanueva, P. "Did the Fiscal Stimulus Work for Universities," in How the Financial Crisis and Great Recession Affected Higher Education. University of Chicago Press, 2013, pp. 263-320.

Dupor, B. “The 2009 Recovery Act: Directly Created and Saved Jobs Were Primarily in Government." Federal Reserve Bank of St. Louis Review, Second Quarter, 2014, 96(2), pp. 123-45; https://doi.org/10.20955/r.96.123-146.

Dupor, B. and McCrory, P. "A Cup Runneth Over: Fiscal Policy Spillovers from the 2009 Recovery Act." Economic Journal, 2018, 128(611), pp. 1476-508; https://doi.org/10.1111/ecoj.12475.

Evans, W. and Owens, E. “COPS and Crime." Journal of Public Economics, 2007, 91, pp. 181-201; https://doi.org/10.1016/j.jpubeco.2006.05.014.

Executive Office of the President of the United States. "Educational Impact of the American Recovery and Reinvestment Act." Domestic Policy Council in Cooperation with the U.S. Department of Education, October 2009; https://www.hsdl.org/?abstract\&did=32124.

Feyrer, J. and Sacerdote, B. "Did the Stimulus Stimulate? Effects of the American Recovery and Reinvestment Act." Dartmouth College, 2012; https://doi.org/10.3386/w16759.

Gordon, N. "Do Federal Grants Boost School Spending? Evidence from Title I." Journal of Public Economics, 2004, 88, pp. 1771-792; https://doi.org/10.1016/j.jpubeco.2003.09.002.

Gramlich, E. "Stimulating the Macroeconomy through State and Local Governments." American Economic Review, 1979, 68, pp. 180-85.

Inman, R. "States in Fiscal Distress." NBER Working Paper 16086, National Bureau of Economic Reseatch, 2010; https://doi.org/10.3386/w16086. 
Knight, B. "Endogenous Federal Grants and Crowd-out of State Government Spending: Theory and Evidence from the Federal Highway Aid Program." American Economic Review, 2002, 92, pp. 71-91; https://doi.org/10.1257/000282802760015612.

Lundqvist, H.; Dahlberg, M. and Mörk, E. "Stimulating Local Government Employment: Do General Grants Work?" American Economic Journal: Economic Policy, 2014, 6, pp. 167-92; https://doi.org/10.1257/pol.6.1.167.

New America Foundation. "Individuals with Disabilities Education Act-Funding Distribution." Federal Education Budget Project, April 2014;

http://febp.newamerica.net/background-analysis/individuals-disabilities-education-act-funding-distribution.

Recovery Accountability and Transparency Board. "Recovery.gov: Download Center Users Guide." 2009; http://www.recovery.gov.

U.S. Department of Education. "Guidance on the State Fiscal Stabilization Fund Program." April 2009a; http://www2.ed.gov/programs/statestabilization/guidance.pdf.

U.S. Department of Education. "Guidance: Funds for Part B of the Individuals with Disabilities Act Made Available under the American Recovery and Reinvestment Act of 2009." July 1, 2009b, revise; http://www2.ed.gov/policy/gen/leg/recovery/guidance/idea-b.pdf.

U.S. Department of Education. "Memorandum: The American Recovery and Reinvestment Act of 2009 Individuals with Disabilities Education Act Part B Grants to States and Preschool Grants." Office of Special Education and Rehabilitative Services, April 1, 2009c (including Enclosures A, B and C).

Wilson, D. "Fiscal Spending Jobs Multipliers: Evidence from the 2009 American Recovery and Reinvestment Act." American Economic Journal: Economic Policy, 2012, 4, pp. 251-82; https://doi.org/10.1257/pol.4.3.251. 
